\title{
The Implementation of E-Planning in the Preparation of the 2019 South Kalimantan Provincial Government Work Plan Documents
}

\author{
Dyka Pratama Adhyaksa*, Andi Tenri Sompa, Muhammad Anshar Nur
}

Masters in Development Administration, Postgraduate Program, Lambung Mangkurat University, Jl. Brigjen H. Hasan Basri, Pangeran, Kec. Banjarmasin Utara, Kota Banjarmasin, Kalimantan Selatan 70123, Indonesia

DOI: $10.36348 /$ sjef.2020.v04i09.003

| Received: 22.08.2020 | Accepted: 30.08.2020 | Published: 03.09.2020

*Corresponding author: Dyka Pratama Adhyaksa

\section{Abstract}

This study aims to describe the implementation and find out the support and obstacles faced by the implementation of eplanning in the preparation of the 2019 South Kalimantan Provincial Government Work Plan Document. This research uses a qualitative approach that will encourage researchers to go into the field to observe directly the activities that are carried out conducted at the research location. Data collection techniques used in this study were observation, interviews, and documentation. Sources of data in this study are primary data, namely records of interviews, results of field observations and data on informants and secondary data in the form of completeness documents from implementing agencies and other research results. The results showed that the implementation of e-planning in the preparation of the 2019 South Kalimantan Provincial Government Work Plan Documents had been carried out well. This can be seen from the compliance and fluency of the e-planning routine, where most SKPDs have complied and the smoothness of the eplanning routine is already good. Although there are still some obstacles such as limited human resources and a lack of support from the heads of related agencies. Even so, the implementation of e-planning has had a good impact, such as the consistency of input and output in the RKPD and Pre-RKA documents and making Work Plan documents easier.

Keywords: Implementation, e-planning, RKPD.

Copyright @ 2020: This is an open-access article distributed under the terms of the Creative Commons Attribution license which permits unrestricted use, distribution, and reproduction in any medium for non-commercial use (NonCommercial, or CC-BY-NC) provided the original author and source are credited.

\section{INTRODUCTION}

Basically, bureaucratic reform is an effort to make fundamental reforms and changes to the system of government administration, especially regarding institutional (organizational) aspects, management and human resources of the apparatus. Bureaucratic reform is carried out in the context of realizing good governance with adaptive characteristics, integrity, high performance, clean and corruption-free, able to serve the public, neutral, prosperous and to achieve good governance requires development with good planning.

Planning is a process or series of several interconnected activities in choosing one of several alternatives about the goals to be achieved by an organization / company. Then choose strategies and methods to achieve these goals. This is followed by setting a budget for implementing these strategies and methods, accompanied by selecting and establishing benchmarks for assessing the level of success of the organization / company in achieving its goals by implementing the strategies and methods that have been previously selected [1-3]. Planning is an important milestone in development. Development is a process that is planned in order to achieve better conditions compared to the previous situation by utilizing the potential of natural and human resources so that they have better value for the benefit of the community [4].

Development planning basically takes place in a period of time so that planning that is drawn up to achieve development goals is always a continuous process loop. Implementation or implementation is a very important step in the policy process or policies are just a dream or a good plan, which is neatly stored in the archive if not implemented [5]. Policy implementation according to Lester and Stewart [6] can be seen from the process, output, and outcomes. Supporting factors for the implementation of public policies include referring to the six main management resources, namely Man (human resources), Money (finances), Materials (logistics), Machine (information), Methods (legitimate), and Market (participation) [7].

The development process in Law Number 25 of 2004 concerning the National Development Planning System and Law Number 23 of 2014 concerning 
Regional Government must start from the preparation of the Regional Government Work Plan (RKPD) which is an elaboration of the Regional Medium-Term Development Plan (RPJMD) and contains the draft regional economic framework, priority regional development programs, and work plans, funding and forward forecasts. The process of preparing regional development planning involves various elements of stakeholders in order to utilize and allocate existing resources in order to improve social welfare in an area within a certain period of time. The preparation of planning documents at the SKPD level is carried out for a period of 1 (one) year called the SKPD Work Plan (Renja). This SKPD Work Plan translates the five-year strategic planning outlined in the SKPD Renstra into annual planning which is more operational in nature. The development planning is formulated in a transparent, responsive, efficient, effective, accountable, participatory, measurable, just and sustainable manner. In accordance with the provisions of Article 15 of Law Number 25 of 2004 concerning the National Development Planning System that planning documents are the responsibility of Bappeda.

Regional Regulation Number 7 of 2017 concerning amendments to Regional Regulation Number 6 of 2016 concerning the 2016-2021 Regional Medium-Term Development Plan (RPJMD) has priority programs, one of which is Bureaucratic Transformation and IT-Based Governance or e-planning applications. The e-planning application is a regional development planning system used in the framework of formulating integrated development planning which is routinely carried out every year replacing the conventional and manual mechanisms for proposing programs and regional development activities (musrenbang) so that the community can monitor the development planning process maximally. Through e-government, government services will take place in a transparent, traceable process, so that it is hoped that the element of irregularities can be avoided and services can be provided more effectively and efficiently.

The implementation of e-planning in the Regional Government of South Kalimantan Province still lacks the resources to become an operator in carrying out e-planning. In addition, the e-planning phenomenon is the emergence of unplanned activities, frequent duplication of activities, and unmeasured activity budgets (benchmarks and performance indicators are unclear). Therefore, it is necessary to strengthen IT infrastructure, strengthen and increase human resource capacity, increase coordination with stakeholders (SKPD and the community), carry out continuous monitoring and evaluation, and develop a sustainable and appropriate information system.

Based on the description above, the author conducted research on the implementation of e-planning in the preparation of the 2019 South Kalimantan
Provincial Government Work Plan Documents. This article is intended to describe the implementation of eplanning in the preparation of the 2019 South Kalimantan Provincial Government Work Plan Documents.

\section{RESEARCH METHODS}

This study uses a qualitative approach that will encourage researchers to go into the field to observe directly the activities carried out at the research location to provide a description or descriptive of the implementation of e-planning in the framework of preparing the work plan document of the Regional Government at Bappeda of South Kalimantan Province. The location of this research is Bappeda South Kalimantan Province. Sources of data in this study are divided into two, namely primary data and secondary data. Primary data is in the form of notes from interviews, results of field observations and data about informants. Meanwhile, secondary data is in the form of completeness documents from the implementing agency and other research results.

Data collection techniques used in this study were observation, interviews, and documentation. Observations are carried out directly by researchers to find out / observe symptoms related to the implementation of e-planning in the Framework of Preparing Local Government Work Plan Documents at Bappeda of South Kalimantan Province. Observations were made to verify the accuracy of the data. The interview technique used is an open interview technique with the intention that informants know that they are being interviewed and also know the purpose of the interview, meaning that the interviewer is free to ask anything based on the interview guide. The informants in this study were taken from representatives of the leadership, staff representatives, and representatives of operators who were involved in the implementation of e-planning in the Framework of Preparing Local Government Work Plan Documents at Bappeda of South Kalimantan Province. The documentation technique is done by collecting pre-existing written data. The documents related to this implementation process are the Regional Medium-Term Development Plan (RPJMD), Strategic Plans (Renstra), and Regional Procurement Work Plans (RKPD).

The data analysis used in this study is an interactive model developed by Miles and Huberman [8] which consists of three steps. The first step is data reduction, reducing data means summarizing, selecting the main things, focusing the important things, looking for themes and patterns. The second step is presenting the data in the form of brief descriptions, charts, relationships between categories, flowcharts, and others. The third step is drawing conclusions (verification). 


\section{RESULTS AND DISCUSSION}

\section{Discussion on the Implementation of E-Planning in} the Preparation of the 2019 South Kalimantan Provincial Government Work Plan Documents

Repley and Franklin stated that successful policy implementation is judged by three things, namely; First, using a measure of the level of compliance, second, measuring the smooth functioning of routine functions, and third, seeing the desired impact [9]. The research findings from the level of compliance with e-planning in the framework of drafting the Work Plan document for the Regional Government of South Kalimantan Province tend to be compliant, but the ceiling size still needs to be readjusted with the respective fields that handle it. However, e-planning has made the planning process transparent and accountable easier. In addition, the results of interviews with several informants also said that the smooth running of the e-planning routine was running quite smoothly although there were still several obstacles such as limited human resources, for example the need for additional programmers. Edwards III [10] said that inadequate human resources (number and ability) resulted in the program being unable to implement it properly because they could not carry out proper supervision. If the number of staff implementing policies is limited, what must be done is to improve the skills/abilities of the implementers to carry out the program. In addition, improving the system for the better is also needed so that it makes it easier for users to use e-planning applications. Transfer of employees or transfer is also an obstacle in itself because it has to reteach new employees.

The existence of e-planning in the preparation of the 2019 South Kalimantan Provincial Government Work Plan Documents has been very helpful. Eplanning simplifies all matters of planning, because it can be done online and the data can be corrected by the system. In addition, e-planning also creates consistency of RKPD and Pre RKA documents between data input and output data.

Based on the results of interviews with several informants, it was known that the implementation of eplanning in the framework of drafting the work plan document for the South Kalimantan provincial government was still not optimal due to several things such as a lack of human resources (HR) for operators, the system still had to be improved and it took time. more to adjust the SKPD ceiling. Therefore, the Provincial Government of South Kalimantan to minimize the natural deficiencies in the application of e-planning can coordinate with the SKPDs within the South Kalimantan Provincial Government in the context of implementing e-planning, so that SKPD commitment can be further increased. Apart from that, the Regional Development Planning Agency of the South Kalimantan Provincial Government can also provide training to employees on the e-planning system so that it is hoped that more operators will increase the implementation of inputs, processes and outputs in the e-planning system. In addition to strengthening infrastructure, increasing coordination with stakeholders, drafting clear regulations, socializing to SKPD, implementing continuous monitoring and evaluation, and developing an e-planning application that is sustainable and as needed must also be of particular concern in maximizing e-planning.

The results of this study are supported by research by Ningsih [11] which found that there are still limited human resources in Bengkalis Regency, both in managing the application itself and human resources who want to concentrate on the planning and budgeting section. In addition, Bengkalis Regency is still faced with infrastructure limitations such as network availability, so that the implementation of e-planning and ebudgeting can only be accessed in certain places. The limitations of features or programs related to information needed by parties involved in e-planning and e-budgeting are also a separate issue. The results of this study are also supported by research conducted by Nugroho [12] who found that the application of ePlanning provides changes that have a positive impact on the development planning process in the City of Surabaya such as alignment between planning documents, accuracy of planning data, timeliness, community participation, and transparency.

Edwards III [10] said that information is an important resource for policy implementation. There are two forms of information, namely information on how to finalize policies and what actions must be taken by the implementer. The second form of information is data supporting compliance with government regulations and laws. The reality in the field is that the central level does not know the needs required by the implementers in the field. Lack of information on how to implement policies has direct consequences such as the implementer is not responsible, or the implementer is not in the workplace, causing inefficient. Policy implementation requires organizational and individual compliance with existing government regulations.

Other resources that are also important are the authority to determine how the program is carried out, the authority to spend/manage finances, both providing money, procuring staff, and procuring supervisors. Facilities needed to implement policies / programs must be fulfilled, such as offices, equipment, and sufficient funds. Without this facility it is impossible for the program to run.

\section{Support and Barriers to E-Planning Implementation in the Preparation of the 2019 South Kalimantan Provincial Government Work Plan Documents}

The preparation of Local Government Work Plan Documents based on e-planning in South Kalimantan Province has received support. This can be 
seen from the existence of compliant SKPDs such as the Education and Culture Office and the Regional Finance Agency of South Kalimantan Province because the SKPD is supported by the Head of the Service and has sufficient Human Resources as operators and understands about the e planning program, so that in carrying out input no data that is not completely filled. However, there are still some SKPDs that have not complied. This non-compliance occurs due to several things such as an over budget ceiling that occurred at the Cooperatives and Small and Medium Enterprises
Office. In addition, the civil service police and fire departments and the public bureau have also not complied because the SKPD has not received full support from the Head of the Service. Another reason for this non-compliance is because there is only one operator to input data in the e-planning application, which sometimes causes the input data to not be filled in completely. Data on SKPD that were compliant and non-compliant in the detailed framework of drafting the South Kalimantan Provincial Government Work Plan Documents can be seen in Table-1 as follows.

Table-1: Obedient and Disobedient SKPD in the Framework of Preparing the Work Plan Document for the Regional Government of South Kalimantan Province

\begin{tabular}{|c|c|c|c|c|}
\hline No & OPD Name & $\begin{array}{l}\text { Ceiling of } 2020 \\
\text { Discussion } \\
\text { Results } \\
\end{array}$ & $\begin{array}{l}\text { Monitoring from } \\
\text { Application } \\
\text { (Final) }\end{array}$ & Description \\
\hline 1 & Department of Education and Culture & $426,518,595,000$ & $426,518,595,000$ & CLEAR \\
\hline 2 & public health Office & $101,886,271,114$ & $101,886,271,114$ & CLEAR \\
\hline 3 & RSUD Ulin Banjarmasin & $65,020,521,277$ & $65,020,521,277$ & CLEAR \\
\hline 4 & RSUD Ansari Saleh & $27,087,110,416$ & $27,087,110,416$ & CLEAR \\
\hline 5 & $\begin{array}{l}\text { Department of Public Works and Spatial } \\
\text { Planning }\end{array}$ & $756,961,025,800$ & $756,961,025,800$ & CLEAR \\
\hline 6 & Public Housing and Settlement Areas Service & $36,365,784,000$ & $36,365,784,000$ & CLEAR \\
\hline 7 & National Unity and Political Body & $12,465,291,000$ & $12,465,291,000$ & CLEAR \\
\hline 8 & Civil Service Police Unit and Fire Brigade & $23,521,842,000$ & $23,781,947,000$ & $\begin{array}{l}\text { Extra Budget Ceiling } \\
\text { (On Process) }\end{array}$ \\
\hline 9 & Regional Disaster Management Agency & $13,798,285,000$ & $13,798,285,000$ & CLEAR \\
\hline 10 & social services & $35,383,576,520$ & $35,383,576,520$ & CLEAR \\
\hline 11 & Office of Manpower and Transmigration & $9,094,908,244$ & $9,094,908,244$ & CLEAR \\
\hline 12 & $\begin{array}{l}\text { Office of Women's Empowerment, Child } \\
\text { Protection }\end{array}$ & $13,132,083,000$ & $13,132,083,000$ & CLEAR \\
\hline 13 & Food Security Service & $9,033,676,000$ & $9,033,676,000$ & CLEAR \\
\hline 14 & Plantation and Animal Husbandry Service & $32,891,296,134$ & $32,891,296,134$ & CLEAR \\
\hline 15 & environmental services & $27,342,000,000$ & $27,342,000,000$ & CLEAR \\
\hline 16 & $\begin{array}{l}\text { Department of Population, Civil Registration } \\
\text { and Family Planning }\end{array}$ & $6,288,801,550$ & $6,288,801,550$ & CLEAR \\
\hline 17 & $\begin{array}{l}\text { Community and Village Empowerment } \\
\text { Service }\end{array}$ & $29,070,600,000$ & $29,070,600,000$ & CLEAR \\
\hline 18 & Communication and Informatics Office & $22,389,638,000$ & $22,389,638,000$ & CLEAR \\
\hline 19 & $\begin{array}{l}\text { Office of Cooperatives and Small and } \\
\text { Medium Enterprises }\end{array}$ & $8,036,633,340$ & $8,256,000,000$ & $\begin{array}{l}\text { Extra Budget Ceiling } \\
\text { (On Process) }\end{array}$ \\
\hline 20 & $\begin{array}{l}\text { One-Stop Integrated Services and Investment } \\
\text { Service }\end{array}$ & $8,960,242,750$ & $8,960,242,750$ & CLEAR \\
\hline 21 & Youth and Sports Service & $121,156,825,295$ & $121,156,825,295$ & CLEAR \\
\hline 22 & Department of Library and Archives & $38,080,475,000$ & $38,080,475,000$ & CLEAR \\
\hline 23 & Regional Financial Agency & $57,694,836,100$ & $57,694,836,100$ & CLEAR \\
\hline 24 & Regional Civil Service Agency & $17,699,607,875$ & $17,699,607,875$ & CLEAR \\
\hline 25 & Human Resources Development Agency & $35,198,794,090$ & $35,198,794,090$ & CLEAR \\
\hline 26 & General Bureau & $10,800,889,500$ & $11,880,978,420$ & $\begin{array}{l}\text { Extra Budget Ceiling } \\
\text { (On Process) }\end{array}$ \\
\hline 27 & Organization Bureau & $4,191,787,000$ & $4,191,787,000$ & CLEAR \\
\hline 28 & Government Bureau & $3,580,000,000$ & $3,580,000,000$ & CLEAR \\
\hline 29 & $\begin{array}{l}\text { Goods / Services Procurement Bureau of } \\
\text { Equipment and Services }\end{array}$ & $21,049,012,500$ & $21,049,012,500$ & CLEAR \\
\hline 30 & Legal Bureau & $7,351,306,000$ & $7,351,306,000$ & CLEAR \\
\hline 31 & $\begin{array}{l}\text { Regional People's Representative Council } \\
\text { Secretariat }\end{array}$ & $147,571,485,250$ & $147,571,485,250$ & CLEAR \\
\hline 32 & Regional Inspectorate & $21,848,708,460$ & $21,848,708,460$ & CLEAR \\
\hline \multirow[t]{2}{*}{33} & Liaison Agency & $5,615,288,000$ & $5,615,288,000$ & CLEAR \\
\hline & TOTAL & 2.157 .087 .196 .215 & 2.158 .829 .652 .499 & Extra Budget Ceiling \\
\hline
\end{tabular}


Handling non-compliance of this SKPD requires coordination with stakeholders, drafting clear regulations, socializing to all SKPDs of the South Kalimantan Provincial Government, implementing monitoring and evaluation on an ongoing basis. So it is hoped that there will be no obstacles in the implementation of e-planning in the Framework of Preparing the Work Plan Document for the Regional Government of South Kalimantan Province and it can run well.

\section{CONCLUSION}

The implementation of e-planning in the Preparation of the Work Plan Document for the Regional Government of South Kalimantan Province in 2019 has been running quite well, although there are still some shortcomings. This can be seen from the level of e-planning compliance in the Preparation of the 2019 South Kalimantan Provincial Government Work Plan Documents where most SKPDs have complied, although there are still a few who have not. This is due to several obstacles such as limited human resources and a lack of support from the head of the related department. The e-planning routine has also run smoothly, although it still has to improve human resources for programmers and improve the system properly. In addition, the impact of e-planning also tends to be quite good due to the consistency of input and output in the RKPD and Pre-RKA documents. In addition, the e-planning impact makes the preparation of Work Plan documents easier.

\section{REFERENCES}

1. Alfatih, 2010. Model Implementasi Kebijakan Publik. Jakarta: Trio Rimba Persada.

2. Edward III, George C. 1980. Implementing Public Policy, Congressional Quarterly Press, Washington.
3. Lester, James P. and Joseph Stewart. 2000. Public Policy: An Evolutionary Approach. Australia: Wadsworth, Second Edition.

4. Nawawi, Hadari, 2003, ManajemenStrategik, Yogyakarta: Gajah Mada University Press

5. Ningsih. 2018. Analisis Penerapan EPlanning dan E-Budgeting Pada Pemerintah Daerah (Studi Kasus Pada Pemerintah Kabupaten Bengkalis).

6. Nugroho, Wahyu. 2017. EPlanning DalamPerencanaan Pembangunan Kota Surabaya.TesisUniversitas. ETD. Universitas Gadjah Mada.

7. Ripley, Ronald B and Grace Franklin. 1986. Policy Implementation Bereaucracy. Chicago : Dorsey Press.

8. Siagian, Sondang P. 2004. Manajemen Sumber Daya Manusia. Jakarta: Bumi Aksara.

9. Soetomo. 2009. Pembangunan Masyarakat "Merangkai Sebuah Kerangka". Yogyakarta: Pustaka Pelajar.

10. Sugiyono. 2012. Metode Penelitian Kuantitatif dan Kualitatif dan R\&D. Alfabeta. Bandung.

11. Terry, George, 2005. Dasar-Dasar Manajemen. Jakarta: PT, Bumi Aksara

12. Wirawan. 2018. Evaluasi Kinerja Sumber Daya Manusia Teori Aplikasi dan Penelitian. Jakarta. Penerbit: Salemba Empat.

13. Peraturan Daerah Nomor 7 tahun 2017 tentang perubahan atas Peraturan Daerah Nomor 6 tahun 2016 tentang Rencana Pembangunan Jangka Menengah Daerah (RPJMD) Tahun 2016-2021

14. Peraturan Dalam Negeri Nomor 13 tahun 2006 tentang Pedoaman Pengelolaan Keuangan Daerah.

15. Undang-Undang Nomor 25 Tahun 2004 tentang Sistem Perencanaan Pembangunan Nasional. 